\title{
POPULASI HAMA PENGGEREK TONGKOL JAGUNG Helicoverpa armigera (LEPIDOPTERA : NOCTUIDAE) DI KABUPATEN BONE BOLANGO PROVINSI GORONTALO
}

\section{POPULATION OF CORN COB BORER Helicoverpa armigera (LEPIDOPTERA: NOCTUIDAE) IN BONE BOLANGO DISTRICT, GORONTALO PROVINCE}

\author{
Ramlan Tuliabu'), J. Pelealu²), J. B. Kaligis's) dan M.F. Dien ${ }^{3)}$ \\ 1)Dinas Pertanian Tanaman Pangan dan Hortikulutura, Provinsi Gorontalo \\ 2)Fakultas Pertanian, Universitas Sam Ratulangi, Manado \\ 3)Perhimpunan Entomologi Cabang Manado \\ e-mail : ramlantuliabu@yahoo.co.id
}

\begin{abstract}
Helicoverpa armigera is one of the important pests in maize in Gorontalo province. The study aims to determine the population of corn cob borer Helicoverpa armigera has been implemented in Bolango Bone regency, Gorontalo Province from March to June 2011 study used a survey method based on the four zoning districts as follows: (1) the northern region districts Tilong Kabila, (2) Suwawa Western region districts namely, (3) the Eastern region districts Kabila, and (4) the South region, namely districts Bone Pante. The results showed that the average population of $\mathrm{H}$. armigera cob borers on maize in Bone regency Bolango highest in the district is 3.75 Kabila Bone tail, then the tail 1.92 Tilongkabila districts, sub-districts and districts tail Kabila 1.83 Suwawa 1,4 tail.
\end{abstract}

Keywords: Helicoverpa armigera, pest population

\begin{abstract}
ABSTRAK
Helicoverpa armigera merupakan salah satu hama penting pada tanaman jagung di Provinsi Gorontalo. Penelitian bertujuan untuk mengetahui populasi hama penggerek tongkol jagung Helicoverpa armigera. Penelitian telah dilaksanakan di Kabupaten Bone Bolango, Provinsi Gorontalo sejak Maret sampai Juni 2011. Penelitian dilakukan secara survei pada empat kecamatan berdasarkan pembagian wilayah sebagai berikut (1) wilayah Utara yaitu kecamatan Tilong Kabila, (2) wilayah Barat yaitu kecamatan Suwawa, (3) wilayah Timur yaitu kecamatan Kabila, dan (4) wilayah Selatan yaitu kecamatan Bone Pante. Hasil penelitian menunjukkan bahwa rata-rata populasi hama penggerek tongkol $\mathrm{H}$. armigera pada tanaman jagung di Kabupaten Bone Bolango tertinggi adalah di kecamatan Kabila Bone 3,75 ekor, kemudian kecamatan Tilongkabila 1,92 ekor, kecamatan Kabila 1,83 ekor dan kecamatan Suwawa 1,4 ekor.

Kata kunci : Helicoverpa armigera, populasi hama
\end{abstract}

Eugenia Volume 21 No. 1 Pebruari 2015 


\section{PENDAHULUAN}

Jagung merupakan bahan makanan pokok utama di Indonesia yang memiliki kedudukan sangat penting setelah beras. Dalam perkembangan ekonomi dewasa ini, disamping sebagai bahan makanan pokok, jagung telah menjadi lebih sangat penting karena merupakan bahan pokok bagi industri pakan ternak. Kandungan jagung dalam pakan ternak mencapai lebih dari 50\% yang apabila harus diimpor, karena produksi dalam negeri tidak cukup, akan menelan devisa yang tidak sedikit.

Indonesia berhasil menjadi negara swasembada jagung tahun 2008 dengan jumlah produksi 16,3 juta ton. Dewan Jagung Indonesia memperkirakan produksi jagung dalam negeri tahun 2009 ini mencapai 17,1 juta ton. Itu artinya potensi ekspor bisa mencapai 1,1 juta ton dari kebutuhan jagung nasional yang hanya 16,3 juta ton (Anonim, 2011b).

Kandungan gizi jagung memiliki komposisi zat-zat makanan yang lebih komplet daripada beras. Selain sebagai sumber utama karbohidrat, bahan pangan pokok penduduk asli Madura, Jawa Timur ini juga mengandung zat gizi lain seperti : Energi (150,00 kal), Protein (1,600 g), Lemak (0,60 g), Karbohidrat (11,40 g), Kalsium (2,00 mg), Fosfor $(47,00 \mathrm{mg})$, Serat $(0,40 \mathrm{~g})$, Besi $(0,30 \mathrm{mg})$, Vit A $(30,00 \mathrm{RE})$, Vit B1 $(0.07 \mathrm{mg})$, Vit B2 $(0,04 \mathrm{mg})$, Vit C $(3,00 \mathrm{mg})$, Niacin, $(60 \mathrm{mg})$. Dengan berbagai kandungan zat yang dimiliki jagung tersebut, tak mengherankan bila jagung juga dikenal sebagai bahan pangan yang cukup berkhasiat antara lain sebagai pembangun otot dan tulang, baik untuk otak dan sistem syaraf, mencegah konstipasi, menurunkan resiko kanker dan jantung, mencegah gigi berlubang, serta minyaknya dapat menurunkan kolesterol darah (Anonim, 2010).

Namun produktivitas dan berbagai manfaat dari jagung dapat terganggu oleh karena serangan hama. Kurang lebih tujuh jenis hama ditemukan di pertanaman jagung antara lain: lundi, rayap, kumbang tanah, ulat tanah, penggerek batang, penggerek tongkol dan lalat bibit. Salah satu hama utama yang menyerang jagung di setiap daerah sentra maupun pengembangan adalah ulat penggerek tongkol Helicoverpa armigera (Baco dan Tandiabang, 1988 dalam Anonim, 2000; wikipedia, 11a).

Serangan hama $\mathrm{H}$. armigera sudah menjadi masalah bagi petani tanaman jagung di Indonesia. Menurut Direktur Jendral Tanaman Pangan Departemen Pertanian, serangan ulat penggerek batang dan tongkol jagung telah membuat potensi kehilangan hasil panen jagung mencapai 40 persen. Serangan hama ini terjadi di hampir seluruh wilayah Indonesia (Anonim, 2008; Wikipedia, 11b).

Mengetahui perkembangan serangan hama penggerek tongkol jagung sangat penting untuk melakukan usaha pengendalian yang efektif.

Penelitian ini bertujuan untuk mengetahui populasi hama penggerek tongkol jagung Helicoverpa armigera di Kabupaten Bone Bolango.

Manfaat dari penelitian ini diharapkan dapat memberi informasi populasi hama penggerek tongkol jagung Helicoverpa armigera di Kabupaten Bone Bolango sehingga dapat membantu usaha pengendalian hama tersebut.

\section{METODE PENELITIAN}

Penelitian dilakukan secara survei yang dilaksanakan sejak Maret-Juni 2011 pada empat kecamatan di Kabupaten Bone Bolango yang merupakan sentra produksi jagung. Keempat kecamatan tersebut ditentukan berdasarkan pembagian wilayah sebagai berikut : Wilayah Utara yaitu Kecamatan Tilong Kabila, Wilayah Barat yaitu Kecamatan Suwawa, Wilayah Timur yaitu Kecamatan Kabila dan Wilayah Selatan yaitu Kecamatan Bone Pante

Setiap kecamatan diambil satu desa sebagai lokasi pengambilan sampel. Kemudian setiap desa ditentukan satu lokasi dengan luas \pm 1 ha. Pengambilan sampel disetiap lokasi menggunakan metode irisan diagonal seperti yang dijelaskan pada Gambar 1, sehingga setiap lokasi terdapat lima sub lokasi. Setiap sub lokasi diambil 20 rumpun. Pengamatan dilakukan pada tanaman berumur 45 hari sampai panen. Pengamatan dilakukan 1 kali setiap minggu. 


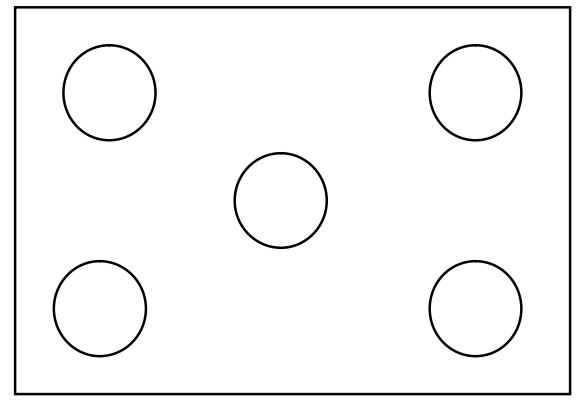

Ket. :

$$
\begin{aligned}
\square & =\text { Unit Sampel } \\
\bigcirc= & \text { Sub Sampel/lokasi }
\end{aligned}
$$

Gambar 1. Metode Pengambilan Sampel Secara Irisan Diagonal

(Figure 1. Method of Sampling Diagonal slices)

\section{Prosedur Penelitian \\ Persiapan}

Persiapan meliputi penentuan lokasi pengambilan sampel penelitian di setiap kecamatan dan desa yang sudah ditentukan, penyiapan bahan dan peralatan yang akan digunakan dalam penelitian.

\section{Pengambilan Hama}

Setiap minggu dilakukan pengamatan pada lokasi pengambilan sampel. Pengambilan hama penggerek tongkol jagung dilakukan pada setiap sub lokasi. Pengambilan hama dilakukan secara langsung mengambil pada tongkol jagung yang sudah diserang hama.

\section{Hal-hal yang Diamati}

Hal-hal yang diamati dalam penelitan ini yaitu penyebaran hama penggerek tongkol jagung di Kabupaten Bone Bolango dengan melihat adanya serangan hama pada unit sampel pengamatan. Pengamatan serangan hama dilakukan pada saat tongkol sudah mulai terbentuk biji yaitu pada tanaman berumur sekitar 45 hari setelah tanam. Pengamatan tanaman terserang dapat ditentukan dengan adanya larva dan pupa hama penggerek tongkol pada tanaman.

\section{HASIL DAN PEMBAHASAN}

Hasil penelitian terhadap populasi hama penggerek tongkol $H$. armigera pada tanaman jagung di Kabupaten Bone Bolango dapat dilihat pada Tabel 1.

Pada tabel 1 terlihat bahwa dari keempat wilayah sesuai 4 arah mata angin sehingga memenuhi 4 kecamatan yaitu wilayah utara Kecamatan Tilongkabila, wilayah barat Kecamatan Suwawa, wilayah timur Kecamatan Kabila dan wilayah selatan Kecamatan Kabila Bone telah dapat ditemukan serangan hama penggerek tongkol $H$. armigera dengan rata-rata populasi tertinggi pada Kecamatan Kabila Bone 3,75 ekor kemudian diikuti kecamatan tilongkabila 1,92 ekor, kecamatan kabila 1,83 ekor dan terakhir Kecamatan Suwawa 1,4 ekor. Hasil penelitian ini menunjukkan bahwa sebaran $H$. armigera telah ditemukan di seluruh wilayah pertanaman jagung yang berada di Kabupaten Bone Bolango walaupun dengan jumlah yang relatif rendah (lihat Gambar 2).

Tabel 1. Rata-Rata Populasi Hama Penggerek Tongkol (H. armigera ) Pada Tanaman Jagung Di Kabupaten Bone Bolango

(Table 1. Average Cob Borer Pest Populations (H. armigera) In Corn Plants In Bone Bolango)

\begin{tabular}{cccccc}
\hline \multirow{2}{*}{ Kecamatan } & \multicolumn{5}{c}{ Rata-Rata Populasi H. armigera (ekor) } \\
\cline { 2 - 6 } & $\mathrm{I}$ & II & III & IV & Rata-Rata \\
\hline Kabila & 2,2 & 1,7 & 1,6 & - & 1,83 \\
Tilongkabila & 2,8 & 2,12 & 0,85 & - & 1,92 \\
Suwawa & 1,55 & 1,45 & 1,2 & - & 1,4 \\
Kabila Bone & 4,1 & 3,95 & 3,2 & - & 3,75 \\
\hline
\end{tabular}




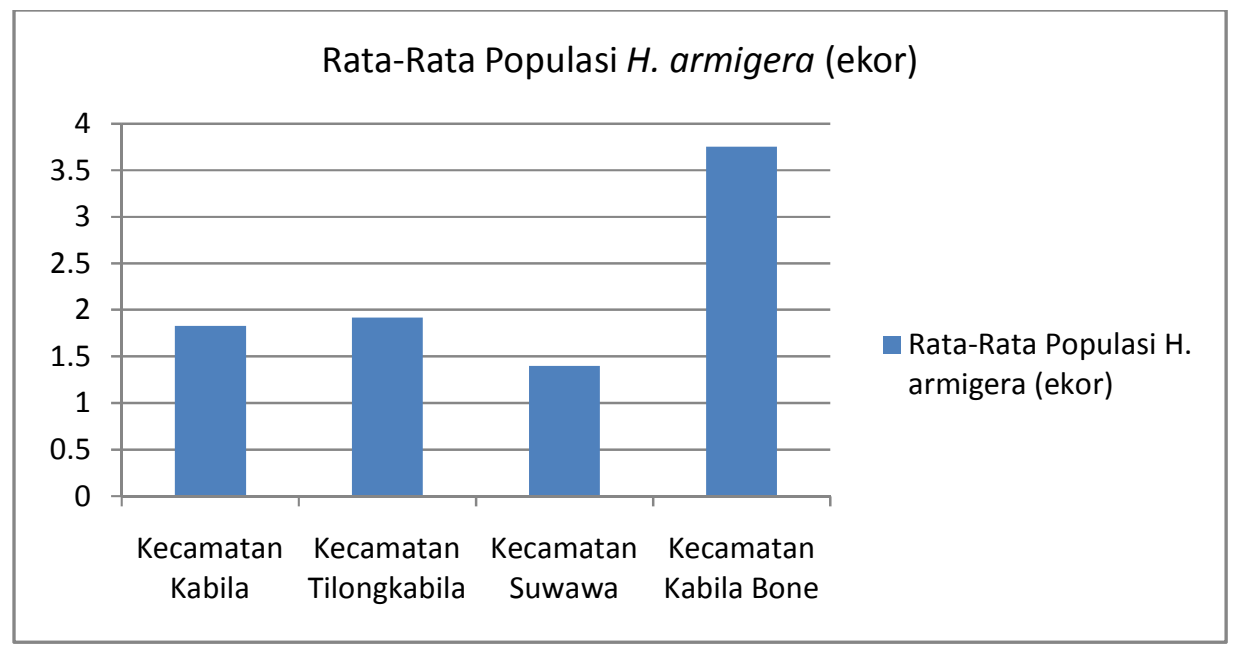

Gambar 2. Rata-Rata Populasi H. armigera yang Ditemukan di Beberapa Kecamatan di Kabupaten Bone Bolango

(Figure 2. Average Population of H. armigera Found in Some Districts in Bone Bolango Regency)

Gambar 2 menunjukan bahwa seluruh areal pertanaman jagung di seluruh kecamatan sampel telah terserang oleh hama penggerek tongkol $H$. armigera. Menurut Sembel (1991) dan Pfadt (1978) bahwa Hama penggerek tongkol $H$. armigera telah tersebar hampir di seluruh dunia dan dapat menyerang semua varitas tanaman jagung yang ada. Lebih lanjut dijelaskan oleh Memah (1986) bahwa hama ini dapat ditemukan pada areal tanaman jagung pada ketinggian $0-900$ meter dari permukaan laut terutama populasinya akan tinggi pada areal pertanaman $800-900$ meter dari permukaan laut. Kalshoven (1981) menyatakan bahwa penyebaran ulat penggerek tongkol dapat ditemukan sampai pada ketinggian 2000 meter dari permukaan laut.

Sebaran hama di lapang merupakan faktor penting yang harus diperhatikan dalam pengendalian sesuatu jenis hama. Hama mempunyai daya adaptasi terhadap lingkungan ia hidup. Menurut Sastrodihardjo (1979) bahwa penyebaran dan kerapatan populasi serangga dapat dipengaruhi oleh perbedaan letak ketinggian tempat yang secara langsung mengakibatkan terjadinya perbedaan dalam hal faktor-faktor iklim. Faktor iklim seperti suhu, kelembaban, curah hujan dan cahaya serta faktor biotis merupakan pengatur populasi serangga. Southwood (1977) menyatakan bahwa penyebaran hama meliputi tiga pola sebara yaitu : (1)
Bila populasi rendah sebaran cenderung menyebar acak, (2) Sebaran populasi yang regular atau merata, dan (3) Bila populasi tinggi sebaran lebih bersifat berkelompok .

Selain itu pula terlihat bahwa rata-rata populasi $H$. armigera di lapang adalah relatif rendah dengan kisaran 1,4-3,75 ekor. Hasil ini diduga disebabkan selain faktor iklim; faktor biotis yaitu berfungsinya musuh alami seperti parasitoid, predator, dan entomopatogen (cendawan, bakteri dan virus di lapang. Menurut Sembel (1991) dan Kalshoven (1981) bahwa di alam serangga hama ini dapat ditekan populasinya oleh musuh alami terutama parasitoid telur yaitu Trichogramma sp. dan Eriborus sp. dan parasitoid larva dari family Icneumonidae.

\section{KESIMPULAN DAN SARAN}

\section{Kesimpulan}

Serangga hama penggerek tongkol $H$. armigera telah tersebar dan dapat ditemukan di seluruh wilayah Kabupaten Bone Bolango. Ratarata populasi $\mathrm{H}$. armigera tertinggi terdapat pada Kecamatan Kabila Bone 3,75 ekor kemudian diikuti Kecamatan Tilongkabila 1,92 ekor, Kecamatan Kabila 1,83 ekor dan terakhir Kecamatan Suwawa 1,4 ekor. 


\section{Saran}

Perlu dilakukan penelitian terhadap peranan musuh-musuh alami $H$. armigera di lapang terutama parasitoid dan predator yang berfungsi dalam menekan populasi serangga hama.

\section{DAFTAR PUSTAKA}

Anonim. 2000. Teknologi Peningkatan Produksi Jagung Bisma di Lahan Kering. Badanlibangtan. BPTP Ungaran. Dep.Tan hal. 21.

2008. Deptan Lakukan Analisis Serangan Hama. (online). http://www.dradio1034fm. or.id/detail.php?id=2846. Diakses 23 Februari 2011.

2010. Manfaat Jagung Bagi Kesehatan. (online). http://www.kaskus.us/showthread. php?t=4507225. Diakses 23 Februari 2011.

2011a. Budidaya Jagung. (online). http://rizalm09.student.ipb.ac.id/pertanianku/budidaya-jagung/. Diakses 23 Februari 2011.

2011b. Indonesia Eksportir Jagung Dunia. (online). http://matanews.com/2009/07/30/ indonesia-eksportir-jagung-dunia/. diakses 23 Februari 2011.

Kalshoven, L.G.E. 1981. The Pests Of Crops In Indonesia. PT Ichtiar Baru-Van Hoeve, Jakarta p. 343.
Memah, V.V. 1986. Pengaruh Ketinggian Tempat Terhadap Padat Populasi Ulat Tongkol Jagung (Heliothis armigera $\mathrm{Hbn}$ ) $\mathrm{Di}$ Wilayah Kabupaten Minahasa. Skripsi S1. Jurusan Hama dan Penyakit Tumbuhan. Fakultas Pertanian Unsrat Manado. 24 hal.

Pfadt, E.R. 1978. Fundamentals of Applied Entomology. The Machmilan Company New York. Collier-Machmillan, London.

Sastrodihardjo. 1979. Pengantar Entomologi Terapan. ITB Bandung. 123 hal.

Sembel, D.T. 1991. Beberapa Serangga Hama Pada Tanaman Padi dan Jagung. Proyek Pengembangan Perguruan Tinggi. Universitas Sam Ratulangi Manado.

Southwood, T.R.E. 1977. Ecological Methods. With Particular Refenrence to The Studi of Insect Population the English Language Book Sosciety and Chapman Hall.

Wikipedia. 2011a. Jagung. (online). http:/id. wikipedia.org/wiki/Jagung. diakses 23 Februari 2011.

Wikipedia, 2011b. Helicoverpa armigera. (online). file://G:/penyebaran\%20hama\%20pengge rek\%20tongkol\%20jagung/Helicoverpa_ar migera.htm. diakses tanggal 23 Februari 2011. 